\title{
OVULATION AND FERTILIZATION IN THE LAMB
}

\author{
R. B. LAND AND P. T. McGOVERN* \\ Animal Breeding Research Organisation, West Mains Road, Edinburgh
}

(Received 28th September 1967)

The experiments described below were undertaken to study the effects of different hormone treatments on follicular development, ovulation and fertilization in lambs. In a similar investigation, Mansour (1959) obtained a low rate of fertilization which he attributed to the use of diluted semen and to the inefficiency of insemination by the vaginal route. In the present experiments fresh undiluted semen was introduced directly into the uterine horns.

Sixteen Scottish Blackface and eight crossbred female lambs were used. The average weight was $16.7 \mathrm{~kg}$ (range 11.5 to $26.5 \mathrm{~kg}$ ). The treatments were begun (Day 0 ) as soon as possible after the lambs were 50 days of age so that ovulation would be expected to occur when the lambs were approximately 9 weeks old.

The treatments were: (a) Daily administration of $3.0 \mathrm{mg}$ progesterone ('Protormone'; Burroughs Wellcome \& Co.) by intra-muscular injection at approximately 11.00 hours from Day 0 to Day 8 inclusive or no treatment with progesterone; (b) Either 350 or 700 i.u. pregnant mares' serum gonadotrophin (PMSG) ('Pregnant Mares Serum'; Burroughs Wellcome \& Co.) by subcutaneous injection at approximately 11.00 hours on Day 10; (c) 500 i.u. human chorionic gonadotrophin (HCG) ('Lutormone'; Burroughs Wellcome \& Co.) by intravenous injection at approximately 15.00 hours on either Day 12 or Day 13 . The treatments were arranged factorially $(2 \times 2 \times 2)$ and lambs were allocated at random to each of the eight groups. Each group was composed of three lambs.

Approximately $20 \mathrm{hr}$ after treatment with HGG, i.e. on the morning of Day 13 or Day 14, the ovaries were examined at laparotomy. A record was made of the numbers of unruptured follicles and corpora lutea; the latter were classified according to their morphology as either recently ovulated follicles or typical corpora lutea. For insemination, $0.1 \mathrm{ml}$ of fresh undiluted ram semen was introduced into the lower part of the uterine horn on the same side as the ovary with the greater number of follicles and corpora lutea. The semen was collected using an artificial vagina and used only if its motility was considered satisfactory. Lambs with ovaries showing no follicular development were not inseminated.

The ovaries were re-examined at laparotomy approximately $48 \mathrm{hr}$ after insemination, i.e. on Day 15 or Day 16, and the number of unruptured follicles and corpora lutea was again recorded. The tubal genitalia were flushed with 2 to $3 \mathrm{ml}$ phosphate buffered saline and a record was made of the number of cleaved and uncleaved eggs recovered.

* Present address: Department of Anatomy, Royal Veterinary College, London, N.W.1. 
At the first examination (time of insemination) a total of fifty-one unruptured follicles, five recently ovulated follicles and fourteen typical corpora lutea was observed. At the second examination (time of egg recovery) there were thirty-one unruptured follicles, twenty-one recently ovulated follicles and

TABLE 1

THE NUMBER OF UNRUPTURED FOLLICLES, RECENTLY OVULATED FOLLICLES AND TYPICAL CORPORA LUTEA PRESENT, AT THE TIME OF EGG RECOVERY, IN THE OVARIES OF LAMBS FOLLOWING TREATMENT WITH DIFFERENT GOMBINATIONS OF PROGESTERONE, PMSG AND HCG

\begin{tabular}{|c|c|c|c|c|c|c|c|c|c|c|}
\hline \multirow{2}{*}{ Progesterone } & \multirow{2}{*}{$\begin{array}{c}\text { Dose of } \\
P M S G \\
(\text { i.u. })\end{array}$} & \multirow{2}{*}{$\begin{array}{c}\text { Interval } \\
P M S G- \\
H C G \\
(\text { days })\end{array}$} & \multirow{2}{*}{$\begin{array}{l}\text { No. of } \\
\text { animals }\end{array}$} & \multirow{2}{*}{$\begin{array}{c}\text { Total no. } \\
\text { of un- } \\
\text { ruptured } \\
\text { follicles }\end{array}$} & \multirow{2}{*}{$\begin{array}{c}\text { Total } \\
\text { no. of } \\
\text { recently } \\
\text { ovulated } \\
\text { follicles }\end{array}$} & \multirow{2}{*}{$\begin{array}{c}\text { Total } \\
\text { no. of } \\
\text { typical } \\
\text { corpora } \\
\text { lutea }\end{array}$} & \multirow{2}{*}{\multicolumn{2}{|c|}{$\begin{array}{l}\text { Total follicular } \\
\text { development } \\
\text { Mean } \pm S . E .\end{array}$}} & \multicolumn{2}{|c|}{$\begin{array}{l}\text { Eggs recovered } \\
\text { from side } \\
\text { inseminated }\end{array}$} \\
\hline & & & & & & & & & Total & $\begin{array}{c}\text { No. } \\
\text { fertilized }\end{array}$ \\
\hline \multirow[t]{2}{*}{ Untreated } & 350 & $\begin{array}{l}2 \\
3\end{array}$ & $\begin{array}{l}3 \\
3\end{array}$ & $\begin{array}{l}3 \\
0\end{array}$ & $\begin{array}{l}0 \\
1\end{array}$ & $\begin{array}{l}1 \\
3\end{array}$ & $\begin{array}{l}1 \cdot 33 \\
1 \cdot 33\end{array}$ & $\begin{array}{l}0.88 \\
0.66\end{array}$ & $\begin{array}{l}0 \\
2\end{array}$ & $\begin{array}{l}0 \\
1\end{array}$ \\
\hline & 700 & $\begin{array}{l}2 \\
3\end{array}$ & $\begin{array}{l}3 \\
3\end{array}$ & $\begin{array}{l}1 \\
5\end{array}$ & $\begin{array}{l}1 \\
2\end{array}$ & $\begin{array}{l}4 \\
4\end{array}$ & $\begin{array}{l}2 \cdot 00 \\
3.67\end{array}$ & $\begin{array}{l}0.58 \\
0.33\end{array}$ & $\begin{array}{l}2 \\
1\end{array}$ & $\begin{array}{l}2 \\
0\end{array}$ \\
\hline \multirow[t]{2}{*}{ Treated } & 350 & $\begin{array}{l}2 \\
3\end{array}$ & $\begin{array}{l}3 \\
3\end{array}$ & $\begin{array}{l}5 \\
2\end{array}$ & $\begin{array}{l}1 \\
0\end{array}$ & $\begin{array}{l}1 \\
1\end{array}$ & $\begin{array}{l}2 \cdot 33 \\
1 \cdot 00\end{array}$ & $\begin{array}{l}0.88 \\
0.58\end{array}$ & $\begin{array}{l}1 \\
1\end{array}$ & $\begin{array}{l}0 \\
0\end{array}$ \\
\hline & 700 & $\begin{array}{l}2 \\
3\end{array}$ & $\begin{array}{l}3 \\
3\end{array}$ & $\begin{array}{r}11 \\
4\end{array}$ & $\begin{array}{r}1 \\
15\end{array}$ & $\begin{array}{r}14 \\
1\end{array}$ & $\begin{array}{l}8 \cdot 67 \\
6 \cdot 67\end{array}$ & $\begin{array}{l}6 \cdot 17 \\
5 \cdot 24\end{array}$ & $\begin{array}{l}7 \\
1\end{array}$ & $\begin{array}{l}4 \\
0\end{array}$ \\
\hline
\end{tabular}

TABle 2

ANALYSIS OF VARIATION IN TOTAL FOLLICULAR DEVELOPMENT

\begin{tabular}{l|r|l}
\hline \multicolumn{1}{c|}{ Source } & d.f. & MS \\
\hline Progesterone & 1 & $0 \cdot 070$ \\
PMSG & 1 & $0 \cdot 524^{*}$ \\
PMSG $\times$ progesterone & 1 & $0 \cdot 010$ \\
Time & 1 & $0 \cdot 146$ \\
Time $\times$ progesterone & 1 & $0 \cdot 156$ \\
Time PMSG & 1 & $0 \cdot 021$ \\
Time $\times$ PMSG $\times$ progesterone & 1 & $0 \cdot 008$ \\
Within groups & 16 & $0 \cdot 113$ \\
\hline
\end{tabular}

$$
* P<0.05 \text {. }
$$

twenty-nine typical corpora lutea, representing an increase in the 'total follicular development' from seventy to eighty-one.

The response of the various treatment groups at the second examination is shown in Table 1. For statistical analysis the data were transformed from [observation] to [log (observation plus 1 )]. Table 2 shows that the only treatment to have a significant effect on the total follicular development is the dose of PMSG; 700 i.u. induced the development of a greater number of follicles than did 350 i.u. Inspection of the data in Table 1 suggests that there is an interaction between progesterone treatment and dose of PMSG, but as it is not possible to analyse the untransformed data, its significance cannot be assessed. 
The effects were tested of the main treatments on the ratios of the number of unruptured follicles to the number of both classes of corpora lutea, and to the number of typical corpora lutea. The only significant effect was that of the time interval between PMSG and HCG on the proportion of typical corpora lutea. Twenty of forty-three follicles formed corpora lutea when the interval was 2 days compared to only nine of thirty-eight when the interval was 3 days $\left(\chi_{(1)}^{2}=4.57 ; 0.5>P>0.02\right)$. Examination of the effect on fertilization of the time between treatment with PMSG and HCG shows that three times as many eggs were fertilized when the interval was 2 days $(6 / 10)$ than were fertilized when the interval was 3 days $(1 / 5)$. The difference, however, is not statistically significant.

Of the thirty-four eggs presumed to have been shed from the ovaries on the side of the inseminated horns, fifteen were recovered, seven of which were cleaved. By contrast, of sixteen eggs presumed to have been shed on the side of the non-inseminated horns, only two eggs were recovered, both of which were uncleaved. The difference in recovery rates is significant $\left(\chi_{(1)}^{2}=4 \cdot 85\right.$; $0.05>P>0.02$ ).

The significantly greater degree of follicular development obtained with the higher dose of PMSG, namely 700 i.u., was anticipated and it is possible that a further increase in the dose of PMSG would be advantageous. Furthermore, the indication of an interaction between the effects of progesterone and the dose of PMSG suggests that pre-treatment of lambs with progesterone is of value when larger doses of PMSG are to be used.

Examination of the effects of varying the interval between PMSG and HCG treatment shows that with the shorter interval the number of follicles which formed typical corpora lutea was greater and there is some evidence that the fertilization rate was also increased.

We wish to thank Professor J. L. Hancock and Mr A. F. Purser for advice and Miss M. N. S. Rennie and Mr S. B. Wilson for technical assistance.

\section{REFERENCE}

Mansour, A. M. (1959) The hormonal control of ovulation in the immature lamb. F. agric. Sci., Camb. 52, 87. 